\title{
Semi-pilot scale-up of a continuous packed-bed bioreactor system developed for the lipase-catalyzed production of pseudo-ceramides
}

\author{
Florian Le Joubioux, Nicolas Bridiau*, Marianne Graber and Thierry Maugard \\ Équipe approches moléculaires, environnement-santé, UMR 7266 CNRS-ULR, LIENSs, université de La Rochelle, \\ avenue Michel-Crépeau, 17042 La Rochelle, France
}

Received 6 February 2017 - Accepted 29 March 2017

\begin{abstract}
Ceramides are sphingolipid compounds that are very attractive as active components in both the pharmaceutical and the cosmetic industries. In this study, the synthesis of 1-O,3- $N$-diacyl3-amino-1,2propanediol-type pseudo-ceramides was developed at the semi-pilot scale, starting from a two-step continuous enzymatic process with immobilized Candida antarctica lipase B (Novozym 435) in a packedbed bioreactor, previously optimized at the laboratory scale. This process involved the selective $N$-acylation of 3-amino-1,2-propanediol (step 1), followed by the selective $O$-acylation of the $N$-acyl 3-amino-1,2propanediol synthesized in the first step, with various fatty acids as acyl donors, to produce $N, O$-diacyl 3-amino-1,2-propanediol-type pseudo-ceramides (step 2). Under partially optimized operating conditions, high synthesis yields and production rates were obtained, within the ranges $76-92 \%$ and $3.7-4.6 \mathrm{~g} \mathrm{~h}^{-1}$ (step 1), or 23-36\% and 1-1.4 $\mathrm{g} \mathrm{h}^{-1}$ (step 2), respectively, depending on the fatty acids used as acyl donors. The overall synthesis yields varied from 20 to 33\%: the best yield was obtained using palmitic acid and lauric acid as first and second acyl donors, respectively. Together with the high production rates also obtained with these acyl donors, this confirms that this two-step process has great potential for the production of differently functionalized 1-O,3- $N$-diacyl 3-amino-1,2-propanediol-type pseudo-ceramides on an industrial scale.
\end{abstract}

Keywords: pseudo-ceramide / continuous bioprocess / packed-bed bioreactor / lipase / semi-pilot scale

\begin{abstract}
Résumé - Passage à l'échelle semi-pilote d'un bioréacteur continu à lit fixe, développé pour la production de pseudo-céramides catalysée par une lipase. Les céramides sont des sphingolipides, composés actifs d'intérêt majeur pour les industries pharmaceutique et cosmétique. Lors de la présente étude, la synthèse de pseudo-céramides de type 1-O,3- $N$-diacyl 3-amino-1,2-propanediol a été développée à l'échelle semi-pilote, à partir d'un procédé enzymatique continu en deux étapes impliquant la lipase B de Candida antarctica (Novozym $\left.{ }^{\circledR} 435\right)$ utilisée au sein d'un bioréacteur à lit fixe, préalablement optimisé à l'échelle du laboratoire. Ce procédé conjuguait la $N$-acylation sélective du 3-amino-1,2-propanediol (étape 1) suivie de la $O$-acylation sélective du $N$-acyl 3-amino-1,2-propanediol synthétisé lors de la première étape, impliquant différents acides gras comme donneurs d'acyles, pour produire des pseudo-ceramides de type N,O-diacyl 3-amino-1,2-propanediol (étape 2). Sous conditions opératoires partiellement optimisées, de hauts rendements de synthèse et vitesses de production ont été obtenus, respectivement de l'ordre de $76-92 \%$ et $3,7-4,6 \mathrm{~g} \mathrm{~h}^{-1}$ (étape 1 ), ou $23-36 \%$ et $1-1,4 \mathrm{~g} \mathrm{~h}^{-1}$ (étape 2 ), en fonction des acides gras utilisés comme donneurs d'acyles. Les rendements de synthèse globaux ont évolué de 20 à $33 \%$ : le meilleur rendement a été obtenu en utilisant respectivement l'acide palmitique et l'acide laurique comme premier et second donneurs d'acyles. Associé à la vitesse de production importante également atteinte avec ces donneurs d'acyles, cela confirme que ce procédé en deux étapes présente un potentiel élevé pour la production à l'échelle industrielle de pseudo-céramides de type 1-O,3- $N$-diacyl 3-amino-1,2-propanediol diversement fonctionnalisés.
\end{abstract}

Mots clés : pseudo-céramide / bioprocédé continu / bioréacteur à lit fixe / lipase / échelle semi-pilote

\footnotetext{
* Correspondence: nicolas.bridiau@univ-lr.fr
} 


\section{Introduction}

Ceramides are natural compounds derived from the $\mathrm{N}$-acylation of sphingosine and are key intermediates in the biosynthesis of all complex sphingolipids. Due to their major role in preserving the water-retaining properties of the epidermis (Coderch et al., 2003), ceramides and their analogs have a wide range of commercial applications, as active ingredients for the cosmetic industry, included in hair and skin care products, or for dermatological therapies: they are indeed effective in restoring the water content of dry skin and in relieving atopic eczema (Kerscher et al., 1991). In addition, their potential antitumor, antiviral (Fillet et al., 2003; Garg et al., 2008) and antioxidant properties (Molina, 2008) make them components of interest for the pharmaceutical industry, which leads to a growing interest in the development and optimization of new processes for their synthesis. Ceramide synthesis is usually performed by acylation of the amino group of a sphingosine, a sphinganine or their derivatives. However, due to the high cost of these compounds, whose chemical synthesis is complex, other approaches have been developed to synthesize ceramide analogs, called pseudoceramides, by the selective acylation of multifunctional compounds such as amino-alcohols. All these compounds are presently synthesized by chemical procedures, which involve several drawbacks: the need of fastidious steps of alcohol group protection and deprotection for the control of selectivity, as well as high temperatures that may preclude the use of fragile molecules and may cause coloration of the end products; the coproduction of salts and the use of toxic solvents (dimethylformamide, methanol, etc.) (Cho et al., 1995; Ha et al., 2006; Philippe and Semeria, 1998; Smeets and Weber, 1997).

In order to overcome these disadvantages, teams, ours included, focused on developing enzymatic syntheses of pseudo-ceramides through immobilized lipase-catalyzed acylation or transacylation reactions carried out in organic solvents (Bakke et al., 1998; Le Joubioux et al., 2014; Smeets et al., 1997). Indeed, using lipases (E.C. 3.1.1.3) can be both selective and more eco-compatible (Haas et al., 2011; Kapoor and Gupta, 2012; Nestl et al., 2011; Sharma et al., 2011), as acylation in organic media provides several advantages such as increasing the solubility of non-polar substrates like fatty acids, eliminating side reactions, making enzyme recovery easier and increasing enzyme thermostability (Doukyu and Ogino, 2010). Multifunctional substrates used for these reactions are amino-alcohols of variable carbon chain length (Fernández-Pérez and Otero, 2003; Furutani et al., 1996; Gotor et al., 1988; Le Joubioux et al., 2013a; Syrén et al., 2013; Torre et al., 2006). In such reactions, it has been shown that the lipases used can catalyze the chemoselective acylation of these substrates in a highly efficient and chemoselective manner, which makes lipases ideal biocatalysts for the synthesis of pseudo-ceramide compounds. Furthermore, the use of continuous-flow technology involving packed-bed bioreactors has become in recent years an innovative, promising and attractive alternative for the highly selective production of pure chemical compounds, providing several advantages: control and automatic operating, reduced costs, significant enhancement in the productivity of the biocatalyst and improvement in quality (less secondary products) and yield (Chang et al., 2007; H-Kittikun et al., 2008).

Starting from this overview, we previously developed an efficient process for the continuous enzymatic production of 1-O,3-N-diacyl 3-amino-1,2-propanediol-type pseudo-ceramides using a packed-bed bioreactor containing immobilized Candida antarctica lipase B (Novozym ${ }^{\circledR} 435$ ) (Le Joubioux et al., 2014). In order to control the chemoselectivity of the reaction, the process was divided into two steps (Scheme 1), for the optimization of the selective diacylation of 3-amino-1,2-propanediol 1 conducted in a tert-amyl alcohol $/ n$-hexane mixture $(50: 50 \mathrm{v} / \mathrm{v})$, starting from various fatty acids as acyl donors: lauric acid $\mathbf{2 a}$, myristic acid $\mathbf{2 b}$, stearic acid $\mathbf{2 d}$ and linoleic acid $\mathbf{2 e .}$

During the first step, the $N$-acylation of 3-amino-1,2propanediol 1, the operational conditions of flow rate, quantity of biocatalyst and substrate concentration were optimized and an excellent synthesis yield of $92 \%$, associated with a very good production rate of $987 \mathrm{mg} \mathrm{h}^{-1}$ were obtained under the best operational conditions, notably involving the use of a $145 \mathrm{~mm}$ long stainless steel column with a $5 \mathrm{~mm}$ inner diameter packed with $875 \mathrm{mg}$ of Novozym ${ }^{\circledR} 435$ to constitute the catalytic bed. During the second step, consisting in the $O$-acylation of the $\mathrm{N}$-acyl 3-amino-1,2-propanediol produced in the first step, we optimized the same operational conditions as in the first step, together with the substrate molar ratio. Under the best conditions identified, the desired pseudo-ceramide, i.e. 1-O-myristyl,3- $\mathrm{N}$ stearyl 3-amino-1,2-propanediol 5d, was produced at a satisfying yield of $54 \%$ and a production rate of $228 \mathrm{mg} \mathrm{h}^{-1}$.

Starting from these statements, we aimed in the present work at evaluating the possibility of scaling up our process to the semi-pilot scale, along with its application to the production of differently functionalized 1-O,3- $N$-diacyl 3-amino-1,2propanediol-type pseudo-ceramides.

\section{Material and methods}

\subsection{Enzymes and chemicals}

Novozym 435 (immobilized C. antarctica lipase B) was kindly provided by Novozymes A/S, Bagsvaerd, Denmark. ( \pm )-3-amino-1,2-propanediol (97\%), lauric acid $(\geq 99 \%)$, palmitic acid $(\geq 98 \%)$, stearic acid $(95 \%)$, linoleic acid $(\geq 99 \%)$ and tert-amyl alcohol (99\%) were purchased from Sigma Aldrich (St Louis, USA) while myristic acid ( $\geq 98 \%$ ) was purchased from Fluka (St Quentin-Fallavier, Switzerland). All chemicals were dried over molecular sieves. Pure water was obtained via a Milli-Q system (Millipore, France). Acetonitrile, methanol, ethanol, $n$-hexane and chloroform were purchased from Carlo Erba (Val-de-Reuil, France).

\subsection{Continuous process using a packed-bed bioreactor system for the Novozym ${ }^{\circledast} 435$-catalyzed synthesis of 1-O,3-N-diacyl 3-amino-1,2-propanediol- type pseudo-ceramides}

\subsubsection{Packed-bed bioreactor system}

The packed-bed bioreactor system used for the continuous two-step enzymatic synthesis of 1-O,3- $\mathrm{N}$-diacyl 3-amino-1,2propanediol-type pseudo-ceramides catalyzed by immobilized C. antarctica lipase B (Novozym ${ }^{\circledR} 435$ ) was adapted from 


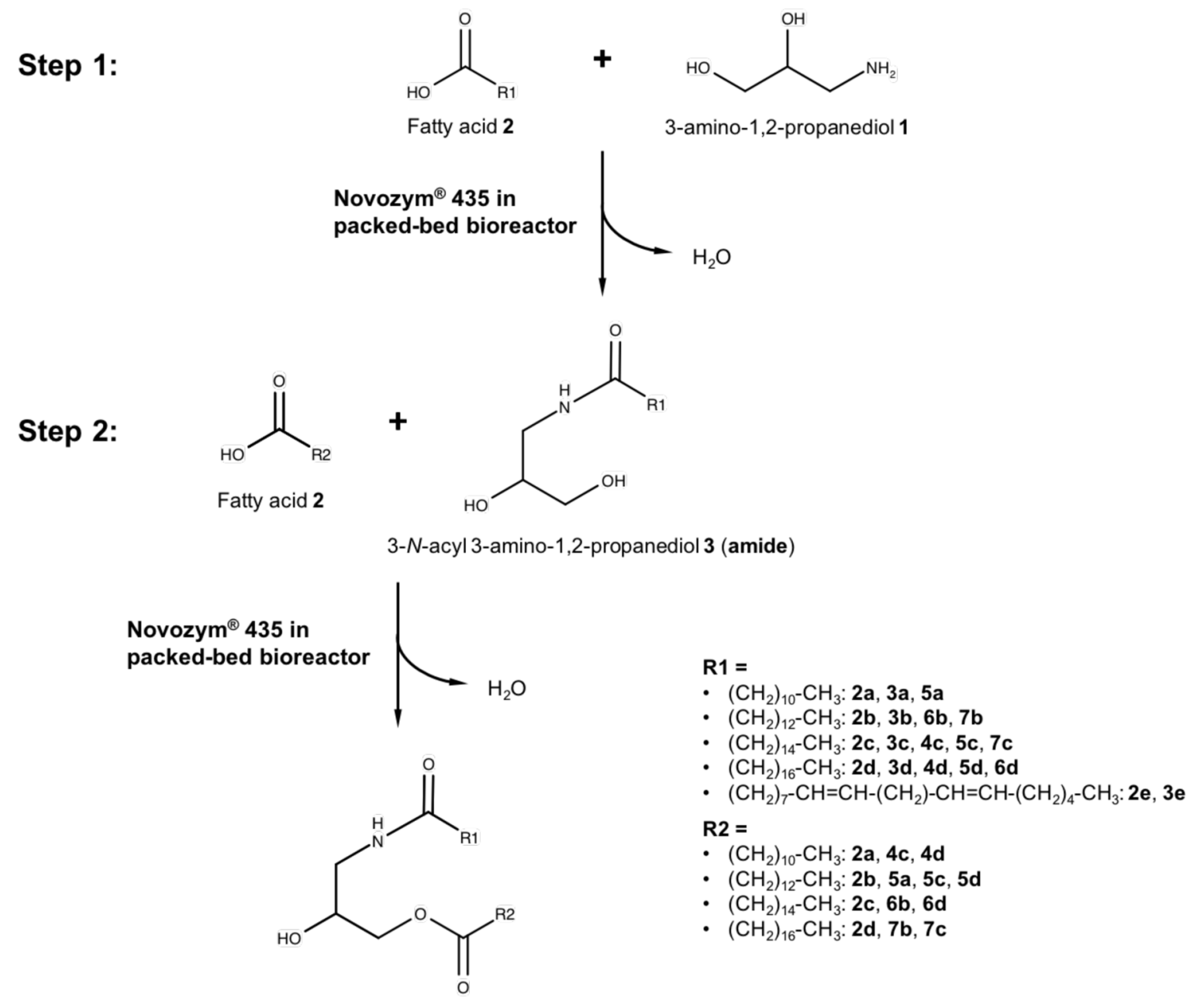

1-O,3-N-diacyl 3-amino-1,2-propanediol 4, 5, 6, or 7 (pseudo-ceramide)

Scheme 1. Two-step process for the selective enzymatic synthesis of 1-O,3- $N$-diacyl 3-amino-1,2-propanediol-type pseudo ceramides catalyzed by Novozym ${ }^{\circledR} 435$ in a packed-bed bioreactor.

the one that we previously developed at the laboratory scale (Le Joubioux et al., 2014). For each step, the reaction mixture (substrates and solvent) was first homogenized for $15 \mathrm{~min}$ at $55^{\circ} \mathrm{C}$ while stirring at $250 \mathrm{rpm}$. A tert-amyl alcohol $/ n$-hexane mixture $(50: 50 \mathrm{v} / \mathrm{v})$ was chosen as the reaction solvent on the basis of previous work that demonstrated the capacity of these two solvents to promote the selective Novozym 435 catalyzed synthesis of amide and amido-ester products starting from various amino-alcohols as substrates (Le Joubioux et al., $2013 b)$. The process was then started by percolating the reaction mixture by means of a peristaltic pump (Minipuls Evolution Peristaltic Pump from Gilson Inc., USA), into a stainless steel $1.5 \mathrm{~cm}$ long column with a $5 \mathrm{~cm}$ inner diameter, packed with Novozym 435 . Throughout the process, the reaction medium leaving the bioreactor was continuously pooled into a product container which, together with the column packed with Novozym 435 , was placed in a temperature-controlled chamber at $55^{\circ} \mathrm{C}$ to promote the synthesis reaction and ensure the solubility of the acylated products. Each step was carried out until the substrate container was empty, indicating the end of the process. The concentration of the remaining substrates and acylated products in the product container were then determined by LC/MS-ESI analysis.

\subsubsection{First step: $N$-acylation of 3-amino-1,2-propanediol}

In the first step, the reaction mixture contained 3-amino1,2-propanediol $\mathbf{1}$, a fatty acid (lauric acid $\mathbf{2 a}$, myristic acid $\mathbf{2 b}$, palmitic acid 2c, stearic acid $\mathbf{2 d}$ or linoleic acid $\mathbf{2 e}$ ), which was used as an acyl donor, and a tert-amyl alcohol/n-hexane mixture $(50: 50 \mathrm{v} / \mathrm{v})$ used as the reaction solvent.

\subsubsection{Liquid-liquid extraction of $N$-acyl 3-amino-1,2- propanediol products}

In order to minimize potential secondary reactions during step 2, a liquid-liquid extraction procedure was performed between steps 1 and 2, after vacuum evaporation of the solvent used in step 1. This extraction was carried out in a separating funnel by adding the obtained dried powder into a water/ ethanol/n-hexane mixture $(25: 25: 50 \mathrm{v} / \mathrm{v} / \mathrm{v})$, at a concentration of $100 \mathrm{~g} \mathrm{~L}^{-1}$, prior to clog the top of the separating funnel and turn it several times, slowly. The mixture was then decanted for 
two hours in order to create a three-phase partitioning involving: a $n$-hexane phase (above) containing the remaining fatty acids, a water/ethanol phase (below) containing the remaining aminoalcohols and an intermediate phase containing the amphiphilic compounds such as $N$-acyl 3-amino-1,2-propanediol. The intermediate phase was recovered and vacuum evaporated to eliminate the remaining solvents and thus obtain the dry $N$-acyl 3-amino-1,2-propanediol-type products. Using this method, we improved the purity of these products before proceeding to step 2. Thus, for all amides with saturated carbon chains, we obtain purities of $91 \%$ (3a), 92\% (3b), 93\% (3c) and 95\% (3d), with improvements in the amide content of up to $9 \%$ for amide 2d. Only the purity of amide $\mathbf{2 e}$ (70\%), exhibiting an unsaturated carbon chain, was shown to decrease by $6 \%$ : for this reason, this amide 2e was not used as acyl acceptor in step 2.

\subsubsection{Second step: O-acylation of $N$-acyl 3-amino-1,2- propanediol products}

In the second step, the reaction mixture contained the $\mathrm{N}$-acyl 3-amino-1,2-propanediol (amide 3a, 3b, 3c or 3d) produced during the first step, a fatty acid (lauric acid $\mathbf{2 a}$, myristic acid $\mathbf{2 b}$, palmitic acid $\mathbf{2 c}$ or stearic acid $\mathbf{2 d}$ ), which was used as an acyl donor, and a tert-amyl alcohol/n-hexane mixture $(50: 50 \mathrm{v} / \mathrm{v})$ used as the reaction solvent.

\subsection{Structural characterization and quantification of reaction products}

To monitor the reactions, $500 \mu \mathrm{l}$ samples were taken from the product container when the continuous process was complete, after about $160 \mathrm{~min}$ of reaction. $500 \mu \mathrm{l}$ of a methanol/chloroform $(50: 50 \mathrm{v} / \mathrm{v})$ were added to each sample in order to homogenize the reaction medium at room temperature. Structural and quantitative analyses of the reaction products (amides and pseudo-ceramides) were then conducted on these samples using a LC/MS-ES system from Agilent (1100 LC/MSD Trap mass spectrometer VL), according to the methodology from Le Joubioux et al. (2014). The amide products were also characterized by infrared (IR) spectroscopy after liquid-liquid extraction and drying. IR spectra were recorded from 400 to 4000 $\mathrm{cm}^{-1}$ with a resolution of $4 \mathrm{~cm}^{-1}$ using a 100 ATR spectrometer (Perkin-Elmer, United States).

\subsubsection{N-lauryl 3-amino-1,2-propanediol 3a}

$\mathrm{m} / \mathrm{z} \quad\left(\mathrm{LR}_{-} \mathrm{ESI}^{+}\right) \quad \mathrm{C}_{15} \mathrm{H}_{32} \mathrm{NO}_{3}\left(\mathrm{M}+\mathrm{H}^{+}\right)$, found: 274.2, calculated for: 274.43 . IR $v_{\max }\left(\mathrm{cm}^{-1}\right): 3307(\mathrm{O}-\mathrm{H}$, alcohol and $\mathrm{N}-\mathrm{H}$, amide), 2800-3000 (CH of lauryl chain), 1631 ( $\mathrm{C}=\mathrm{O}$, amide), 1545 (N-H, amide).

\subsubsection{N-myristyl 3-amino-1,2-propanediol 3b}

$\mathrm{m} / \mathrm{z}$ (LR-ESI $\left.{ }^{+}\right) \quad \mathrm{C}_{17} \mathrm{H}_{36} \mathrm{NO}_{3}\left(\mathrm{M}+\mathrm{H}^{+}\right)$, found: 302.1, calculated for: 302.47 . IR $v_{\max }\left(\mathrm{cm}^{-1}\right): 3298(\mathrm{O}-\mathrm{H}$, alcohol and $\mathrm{N}-\mathrm{H}$, amide), 2800-3000 (CH of myristyl chain), 1634 ( $\mathrm{C}=\mathrm{O}$, amide), 1546 (N-H, amide).

\subsubsection{N-palmitoyl 3-amino-1,2-propanediol 3c}

$\mathrm{m} / \mathrm{z} \quad\left(\mathrm{LR}-\mathrm{ESI}^{+}\right) \mathrm{C}_{21} \mathrm{H}_{42} \mathrm{NO}_{3}\left(\mathrm{M}+\mathrm{H}^{+}\right)$, found: 330.3, calculated for: 330.53 . IR $v_{\max }\left(\mathrm{cm}^{-1}\right): 3312(\mathrm{O}-\mathrm{H}$, alcohol and $\mathrm{N}-\mathrm{H}$, amide), 2800-3000 (CH of palmitoyl chain), 1633 ( $\mathrm{C}=\mathrm{O}$, amide), 1544 ( $\mathrm{N}-\mathrm{H}$, amide).

\subsubsection{N-stearyl 3-amino-1,2-propanediol 3d}

$\mathrm{m} / \mathrm{z}\left(\mathrm{LR}-\mathrm{ESI}^{+}\right) \quad \mathrm{C}_{21} \mathrm{H}_{44} \mathrm{NO}_{3}\left(\mathrm{M}+\mathrm{H}^{+}\right)$, found: 358.2 , calculated for: 358.58 . IR $v_{\max }\left(\mathrm{cm}^{-1}\right): 3312(\mathrm{O}-\mathrm{H}$, alcohol and $\mathrm{N}-\mathrm{H}$, amide), 2800-3000 (CH of stearyl chain), 1633 ( $\mathrm{C}=\mathrm{O}$, amide), 1544 (N-H, amide).

\subsubsection{N-linoleyl 3-amino-1,2-propanediol 3e}

$\mathrm{m} / \mathrm{z}$ (LR-ESI $\left.{ }^{+}\right) \quad \mathrm{C}_{21} \mathrm{H}_{40} \mathrm{NO}_{3}\left(\mathrm{M}+\mathrm{H}^{+}\right)$, found: 354.1, calculated for: 354.56 . IR $v_{\max }\left(\mathrm{cm}^{-1}\right): 3303(\mathrm{O}-\mathrm{H}$, alcohol and N-H, amide), 2800-3000 (CH of linoleyl chain), 1634 ( $\mathrm{C}=\mathrm{O}$, amide), 1548 (N-H, amide).

\subsubsection{1-O-lauryl,3- $N$-palmitoyl 3-amino-1,2-propanediol 4c}

$\mathrm{m} / \mathrm{z}$ (LR-ESI ${ }^{+}$) $\mathrm{C}_{31} \mathrm{H}_{62} \mathrm{NO}_{4} \mathrm{Na}\left(\mathrm{M}+\mathrm{Na}^{+}\right)$, found: 534.4, calculated for: 534.82 .

\subsubsection{1-O-lauryl,3- $N$-stearyl 3-amino-1,2-propanediol 4d}

$\mathrm{m} / \mathrm{z}$ (LR-ESI ${ }^{+}$) $\mathrm{C}_{33} \mathrm{H}_{66} \mathrm{NO}_{4} \mathrm{Na}\left(\mathrm{M}+\mathrm{Na}^{+}\right)$, found: 562.5, calculated for: 562.88 .

\subsubsection{1-O-myristyl,3-N-lauryl 3-amino-1,2-propanediol 5a}

$\mathrm{m} / \mathrm{z}$ (LR-ESI ${ }^{+}$) $\mathrm{C}_{29} \mathrm{H}_{58} \mathrm{NO}_{4} \mathrm{Na}\left(\mathrm{M}+\mathrm{Na}^{+}\right)$, found: 506.4, calculated for: 506.77 .

\subsubsection{1-O-myristyl,3- $N$-palmitoyl 3-amino-1,2-propanediol 5c}

$\mathrm{m} / \mathrm{z}$ (LR-ESI $\left.{ }^{+}\right) \mathrm{C}_{33} \mathrm{H}_{66} \mathrm{NO}_{4} \mathrm{Na}\left(\mathrm{M}+\mathrm{Na}^{+}\right)$, found: 562.5 , calculated for: 562.87 .

\subsubsection{1-O-myristyl,3- $N$-stearyl 3-amino-1,2-propanediol 5d}

m/z (LR-ESI $\left.{ }^{+}\right) \mathrm{C}_{35} \mathrm{H}_{70} \mathrm{NO}_{4} \mathrm{Na}\left(\mathrm{M}+\mathrm{Na}^{+}\right)$, found: 590.2, calculated for: 590.94 .

\subsubsection{1-O-palmitoyl,3-N-myristyl 3-amino-1,2-propanediol $6 \mathrm{~b}$ \\ $\mathrm{m} / \mathrm{z}\left(\mathrm{LR}-\mathrm{ESI}^{+}\right) \mathrm{C}_{33} \mathrm{H}_{66} \mathrm{NO}_{4} \mathrm{Na}\left(\mathrm{M}+\mathrm{Na}^{+}\right)$, found: 562.5 , calculated for: 562.87 .}

\subsubsection{1-O-palmitoyl,3-N-stearyl 3-amino-1,2-propanediol $6 d$}

m/z (LR-ESI $\left.{ }^{+}\right) \mathrm{C}_{37} \mathrm{H}_{74} \mathrm{NO}_{4} \mathrm{Na}\left(\mathrm{M}+\mathrm{Na}^{+}\right)$, found: 618.5, calculated for: 618.98 .

\subsubsection{1-O-stearyl,3-N-myristyl 3-amino-1,2-propanediol 7b}

$\mathrm{m} / \mathrm{z}\left(\mathrm{LR}-\mathrm{ESI}^{+}\right) \mathrm{C}_{35} \mathrm{H}_{70} \mathrm{NO}_{4} \mathrm{Na}\left(\mathrm{M}+\mathrm{Na}^{+}\right)$, found: 590.2, calculated for: 590.94 .

\subsubsection{1-O-stearyl,3-N-palmitoyl 3-amino-1,2-propanediol $7 c$}

m/z (LR-ESI $\left.{ }^{+}\right) \mathrm{C}_{37} \mathrm{H}_{74} \mathrm{NO}_{4} \mathrm{Na}\left(\mathrm{M}+\mathrm{Na}^{+}\right)$, found: 618.5 , calculated for: 618.98 . 
Table 1. Comparison of efficiency between the laboratory and semi-pilot scales of the continuous packed-bed bioreactor system.

\begin{tabular}{|c|c|c|c|c|c|c|c|c|c|}
\hline $\begin{array}{l}\text { Bioreactor } \\
\text { scale }\end{array}$ & Step & \multicolumn{6}{|c|}{ Operational parameters } & Yield (\%) & $\begin{array}{l}\text { Production } \\
\text { rate }\left(\mathrm{g} \mathrm{h}^{-1}\right)\end{array}$ \\
\hline \multirow[b]{2}{*}{ Laboratory $^{\mathrm{a}}$} & 1 & 0.5 & 5.7 & \multirow[b]{2}{*}{0.875} & 100 & 100 & \multirow[b]{2}{*}{$14.5 / 0.5$} & 92 & 0.99 \\
\hline & 2 & 0.25 & 11.4 & & 150 & 50 & & 54 & 0.23 \\
\hline Semi-pilot & 1 & 2.5 & 11.6 & 10 & 100 & 100 & $1.5 / 5$ & 86 & 4.60 \\
\hline
\end{tabular}

\footnotetext{
${ }^{a}$ From Le Joubioux et al. (2014).

${ }^{\mathrm{b}}$ Stearic acid 2d in step 1 and myristic acid $\mathbf{2 b}$ in step 2.

c 3-amino-1,2-propanediol 1 in step 1 and $N$-stearyl 3-amino-1,2-propanediol 3d in step 2.
}

\section{Results and discussion}

The continuous enzymatic synthesis of 1-O,3- $N$-diacyl 3-amino-1,2-propanediol-type pseudo-ceramides catalyzed by immobilized $C$. antarctica lipase B (Novozym ${ }^{635}$ ) was conducted in a semi-pilot scaled-up packed-bed bioreactor system (Scheme 1) in two steps, according to the process previously developed at the laboratory scale (Le Joubioux et al., 2014). The operating conditions applied were very similar from those optimized at this scale, except that a stainless steel $1.5 \mathrm{~cm}$ long column with a $5 \mathrm{~cm}$ inner diameter, packed with Novozym 435 , was used, giving a biocatalyst amount of $10 \mathrm{~g}$, more than 10 -fold higher (Tab. 1). Taking into account this fact, we chose to maintain the residence time optimized for the second step, close to $11.5 \mathrm{~min}$, and increased the flow rate by a factor 10 , reaching $2.5 \mathrm{ml} \mathrm{min}^{-1}$. Besides, various fatty acids were tested as acyl donors: lauric acid 2a (C12:0), myristic acid 2b (C14:0), palmitic acid 2c (C16:0), stearic acid 2d (C18:0) and linoleic acid 2e (C18:2). Natural ceramides are mostly composed of long-chain saturated fatty acids. C18:0 fatty acids are indeed one of the most abundant fatty acids incorporated in the natural ceramides located in the outer layer of the skin, namely the stratum corneum (Bijani, 2010; Schnaar et al., 2009; Wertz et al., 1985). This is one of the reasons why our previous studies aimed at synthesizing pseudo-ceramides composed of long-chain saturated fatty acids, e.g. stearic acid 2d (C18:0) and myristic acid $2 \mathbf{b}$ (C14:0). However, the present study had also for purpose to evaluate the feasibility of producing differently functionalized pseudo-ceramides, involving fatty acids of shorter chain, such as lauric acid 2a (C12:0), or unsaturated fatty acids, such as linoleic acid 2e (C18:2).

Prior to test all these acyl donors, we decided to carry out the first semi-pilot scale production using the acyl donors involved in our previous study, i.e. stearic acid $\mathbf{2 d}$ in step 1 and myristic acid 2b in step 2, to evaluate the impact of the scale-up on the efficiency of the process (Tab. 1).

During the first step, the chemoselective $\mathrm{N}$-acylation of 3-amino-1,2-propanediol 1, the synthesis yield was almost maintained, slightly decreasing from $92 \%$ at the laboratory scale to $86 \%$ at the semi-pilot scale. More interestingly, the production rate of amide 3d ( $N$-stearyl 3-amino-1,2-propanediol) was strongly enhanced, by a factor 4.5 , reaching $4.6 \mathrm{~g} \mathrm{~h}^{-1}$. During the second step, consisting in the $O$-acylation of $N$-stearyl 3-amino-1,2-propanediol produced in the first step, the expected pseudo-ceramide, i.e. 1-O-myristyl,3- $N$-stearyl 3-amino-1,2propanediol 5d, was produced. Nevertheless, the semi-pilot scale-up of the continuous packed-bed bioreactor system was obviously less efficient regarding the synthesis yield of this product, close to $25 \%$, whereas it reached $54 \%$ at the laboratory scale. However, despite this decrease in synthesis yield, the process was still satisfying in terms of production rate of this pseudo-ceramide, which was of $1.10 \mathrm{~g} \mathrm{~h}^{-1}$. This result was all the more attractive since we previously demonstrated that immobilized $C$. antarctica lipase B (Novozym ${ }^{\circledR} 435$ ) was very stable under these operating conditions, showing absolutely no loss of activity even after 22 days of catalysis during step 1 (Le Joubioux et al., 2014). This indicates that the present semi-pilot scaled-up continuous packed-bed bioreactor system would allow to produce about $581 \mathrm{~g}$ of pseudo-ceramide $\mathbf{5 d}$ during the same period of time.

Starting from this encouraging result, we applied the semipilot scaled-up continuous packed-bed bioreactor system to the production of differently functionalized pseudo-ceramides, using the same operating conditions with various fatty acids as acyl donors, for both steps 1 and 2 (Figs. 1 and 2). The first step of $N$-acylation of 3-amino-1,2-propane-2-ol 1 was very efficient, whatever the fatty acid used as an acyl donor (Fig. 1). Indeed, the synthesis yields in amide were very similar and close to $90 \%$ for the four reactions involving saturated fatty acids. The $N$-acylation reaction using linoleic acid $2 \mathbf{e}$ was less interesting, giving $76 \%$ amide yield. The production rates were also similar, ranging from $3.7 \mathrm{~g} \mathrm{~h}^{-1}$ with lauric acid $2 \mathrm{a}$ to $4.5 \mathrm{~g} \mathrm{~h}^{-1}$ with stearic acid $2 \mathrm{~d}$.

These results are of great interest because they both highlight the feasibility of adapting the process to many fatty acids as acyl donors, giving access to differently functionalized pseudo-ceramides, and allow to envisage further pilot or industrial scale-up of the process without a loss in efficiency during this step.

In step 2, the 1-O,3- $\mathrm{N}$-diacyl 3-amino-1,2-propanedioltype pseudo-ceramides were then produced from the selective $\mathrm{O}$-acylation of the $\mathrm{N}$-acyl3-amino-1,2-propanediol (amide) synthesized in step 1 (Fig. 2), starting from the four saturated fatty acids already used as acyl donors in step 1 .

Neither amide 3e nor linoleic acid 2e were tested as acyl acceptor and donor, respectively, owing to the low purity of the former ( $70 \%$ after liquid-liquid extraction and drying), and the low amide yield obtained with the latter during step 1. As expected regarding the results previously obtained at the 


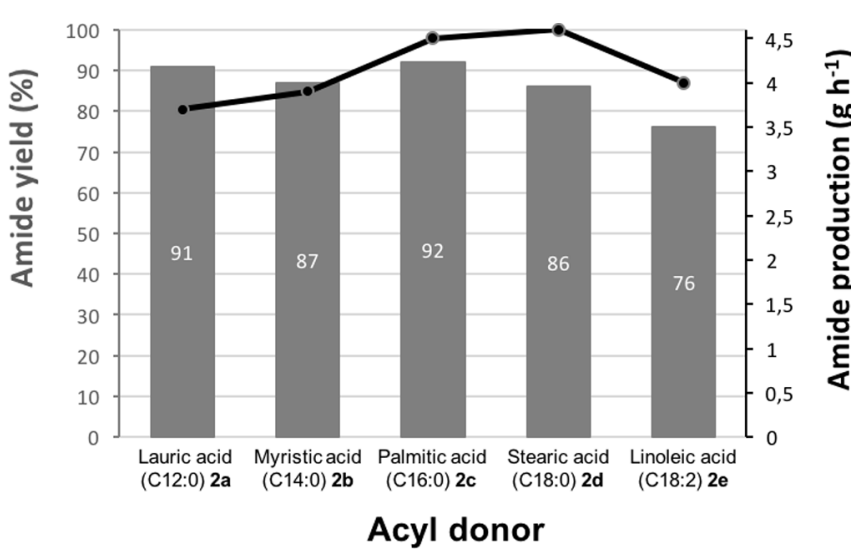

Fig. 1. Effect of the nature of the fatty acid used as an acyl donor on the synthesis yield (histogram) and production rate $(\bullet)$ of the $N$-acyl 3-amino-1,2-propanediol (amide) produced in step 1, using 3-amino1,2-propanediol $\mathbf{1}$ as the acyl acceptor and various fatty acids as acyl donors.
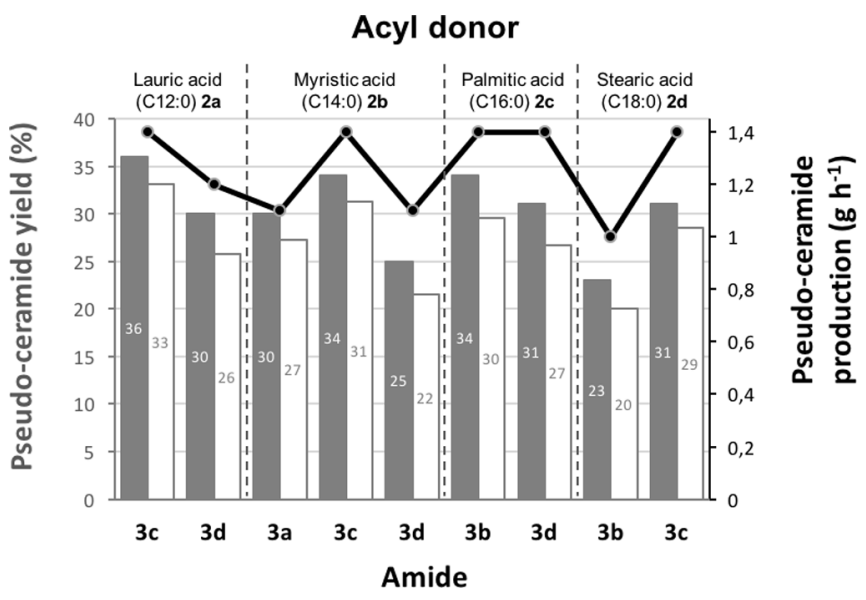

Fig. 2. Effect of the nature of the fatty acid used as an acyl donor on the synthesis yield (grey histogram), the overall synthesis yield (blank histogram) and the production rate $(\bullet)$ of the 1-O,3- $\mathrm{N}$-diacyl 3-amino-1,2-propanediol (pseudo-ceramide) produced in step 2, using various amides synthesized in step 1 as acyl acceptors and various fatty acids as acyl donors.

laboratory scale (Le Joubioux et al., 2014), C. antarctica lipase $\mathrm{B}$ was capable of catalyzing the regioselective acylation of the alcohol 1 of all tested amides, no matter what saturated fatty acid was used as an acyl donor (Scheme 1). Moreover, both the synthesis yields in pseudo-ceramides and their production rates were very similar, as already observed in step 1, ranging within $23-36 \%$ and $1-1.4 \mathrm{~g} \mathrm{~h}^{-1}$, respectively. This emphasizes the fact that step 2 is the limiting step of the process, as confirmed by the overall yields obtained, which were just slightly lower than the pseudo-ceramide yields. These results are also in line with the previous ones we had when we explored the operating conditions of the process for the production of 1-O-myristyl,3- $\mathrm{N}$-stearyl 3-amino-1,2-propanediol 5d in particular, at the laboratory scale (Le Joubioux et al., 2014): the best yield obtained at this scale was indeed of $54 \%$ under optimized conditions (Tab. 1). This difference most likely comes from the reactor design, which involved in the present study a column with a length-to-diameter ratio of about 0.3 whereas the optimal range was demonstrated to be within 12.5-29, to minimize external mass transfer limitation (Le Joubioux et al., 2014). This means that further development of our continuous process including its pilot scale-up would necessarily need to take this optimal design into account, by increasing only the length of the column used to reach this optimal length-to-diameter ratio, in order to maintain the optimum yield of step 2 obtained at the laboratory scale.

\section{Conclusion}

In this work, the production of 1-O,3- $N$-diacyl 3-amino1,2-propanediol-type pseudo-ceramides was developed at the semi-pilot scale, starting from a two-step continuous enzymatic process with immobilized $C$. antarctica lipase B (Novozym 435 ) in a packed-bed bioreactor, previously optimized at the laboratory scale (Le Joubioux et al., 2014). Under partially optimized operating conditions, high synthesis yields and production rates were obtained, within the ranges $76-92 \%$ and $3.7-4.6 \mathrm{gh}^{-1}$ (step 1 of chemoselective $\mathrm{N}$ acylation), or $23-36 \%$ and $1-1.4 \mathrm{~g} \mathrm{~h}^{-1}$ (step 2 of regioselective $\mathrm{O}$-acylation), respectively, depending on the fatty acids used as acyl donors. The overall synthesis yields varied from 20 to $33 \%$ : the best yield was obtained using palmitic acid and lauric acid as first and second acyl donors, respectively. Together with the high production rates also obtained with these acyl donors, this confirms that this two-step process has great potential for the production of differently functionalized 1$O, 3$ - $N$-diacyl 3-amino-1,2-propanediol-type pseudo-ceramides on an industrial scale. This assumption is indeed strengthened by the fact that the productivity of pseudoceramide synthesis for this process was approximately improved by a factor 6 , compared to the previous laboratory scale process.

Acknowledgments. This study was supported by the Centre national de la recherche scientifique and the French National Research Agency (ANR) through the EXPENANTIO project (CP2P program: chimie et procédés pour le développement durable).

\section{References}

Bakke M, Takizawa M, Sugai T, Ohta H. 1998. Lipase-catalyzed enantiomeric resolution of ceramides. J Org Chem 63: 69296938.

Bijani C. 2010. Les lipoamino-acides : des vecteurs d'absorption pour l'administration transmembranaire de biomolécules. $\mathrm{PhD}$ Thesis.

Chang SW, Shaw JF, Yang CK, Shieh CJ. 2007. Optimal continuous biosynthesis of hexyl laurate by a packed bed bioreactor. Process Biochem 42: 1362-1366.

Cho SH, Frew LJ, Chandar P, Madison SA. 1995. Synthetic ceramides and their use in cosmetic compositions. US patent $5476671 \mathrm{~A}$.

Coderch L, López O, De la Maza A, Parra JL. 2003. Ceramides and skin function. Am J Clin Dermatol 4: 107-129.

Doukyu N, Ogino N. 2010. Organic solvent-tolerant enzymes. Biochem Eng J 48: 270-282. 
Fernández-Pérez M, Otero C. 2003. Selective enzymatic synthesis of amide surfactants from diethanolamine. Enzyme Microb Technol 33: $650-660$.

Fillet M, Bentires-Alj M, Deregowski V, et al. 2003. Mechanisms involved in exogenous $\mathrm{C} 2$ - and C6-ceramide-induced cancer cell toxicity. Biochem Pharmacol 65: 1633-1642.

Furutani T, Furui M, Ooshima H, Kato J. 1996. N-acylation of aminoalcohol by acyl migrations following enzyme catalyzed esterification. Enzyme Microb Technol 19: 578-584.

Garg H, Francella N, Tony KA, et al. 2008. Glycoside analogs of betagalactosylceramide, a novel class of small molecule antiviral agents that inhibit HIV-1 entry. Antiviral Res 80: 54-61.

Gotor V, Brieva R, Rebolledo F. 1988. Enantioselective acylation of amino-alcohols by porcine pancreatic lipase. J Chem Soc Chem Commun (14): 957-958.

H-Kittikun A, Kaewthong W, Cheirsilp B. 2008. Continuous production of monoacylglycerols from palm olein in packedbed reactor with immobilized lipase PS. Biochem Eng J 40: 116120.

Ha HJ, Hong MC, Ko SW, Kim YW, Lee WK, Park J. 2006. Synthesis of constrained ceramide analogs and their potent antileukemic activities. Bioorg Med Chem Lett 16: 1880-1883.

Haas MJ, Fox PS, Foglia TA. 2011. Lipase-catalyzed synthesis of partial acylglycerols of acetoacetate. Eur J Lipid Sci Technol 113: 168-179.

Kapoor M, Gupta MN. 2012. Lipase promiscuity and its biochemical applications. Process Biochem 47: 555-569.

Kerscher M, Korting HC, Schäfer-Korting M. 1991. Skin ceramides: structure and function. Eur J Dermatol 1: 39-43.

Le Joubioux F, Bridiau N, Ben Henda Y, Achour O, Graber M, Maugard T. 2013a. The effect of substrate structure on the chemoselectivity of Candida antarctica lipase B-catalyzed acylation of amino-alcohols. J Mol Catal B Enzym 85-86: 193-199.
Le Joubioux F, Bridiau N, Ben Henda Y, Achour O, Graber M, Maugard T. 2013b. The control of Novozym 435 chemoselectivity and specificity by the solvents in acylation reactions of amino-alcohols. J Mol Catal B Enzym 95: 99-110.

Le Joubioux F, Bridiau N, Sanekli M, Graber M, Maugard T. 2014. Continuous lipase-catalyzed production of pseudo-ceramides in a packed-bed bioreactor. J Mol Catal B Enzym 109: 143-153.

Molina JF. 2008. Omega ceramide technology. An active molecule stabilization and transportation system to preserve and strengthen the integrity of the skin. Househ Pers Care Today 2: 12-15.

Nestl BM, Nebel BA, Hauer B. 2011. Recent progress in industrial biocatalysis. Curr Opin Chem Biol 15: 187-193.

Philippe M, Semeria D. 1998. Process for the preparation of ceramide compounds. European patent 0884305 A1.

Schnaar R, Suzuki A, Stanley P. 2009. Glycosphingolipids. In Varki A, Cummings RD, Esko JD, Freeze HH, Stanley P, Bertozzi CR, Hart GW, Etzler ME, eds. Essentials of glycobiology, 2nd ed. New York (USA): Cold Spring Harbor Laboratory Press, 129-142.

Sharma D, Sharma B, Shukla AK. 2011. Biotechnological approach of microbial lipase: a review. Biotechnology 10: 23-40.

Smeets JWH, Weber PG. 1997. Selective N-acylation of aminoalcohols. US patent 5631356 A.

Smeets JWH, De Pater RM, Lambers JWJ. 1997. Enzymatic synthesis of ceramides and hybrid ceramides. US patent $5610040 \mathrm{~A}$.

Syrén P-O, Le Joubioux F, Ben Henda Y, Maugard T, Hult K, Graber M. 2013. Proton shuttle mechanism in the transition state of lipase-catalyzed N-acylation of amino-alcohols. ChemCatChem 5: $1842-1853$.

Torre O, Gotor-Fernández V, Gotor V. 2006. Lipase-catalyzed resolution of chiral 1,3-amino-alcohols: application in the asymmetric synthesis of (S)-dapoxetine. Tetrahedron Asymmetry 17: 860-866.

Wertz PW, Miethke MC, Long SA, Strauss JS, Downing DT. 1985. The composition of the ceramides from human stratum corneum and from comedones. J Invest Dermatol 5: 410-412.

Cite this article as: Le Joubioux F, Bridiau N, Graber M, Maugard T. 2017. Semi-pilot scale-up of a continuous packed-bed bioreactor system developed for the lipase-catalyzed production of pseudo-ceramides. OCL 24(4): D406. 